show that the number of volumes noticed in a particular field follows roughly the number published; thus mathematics and physies heads the subject list of publications both as regards number published and number received for notice, and a larger number of

Table II.-Books Reviewed IN NATURE DURING 1931

\begin{tabular}{|c|c|c|c|}
\hline & $\begin{array}{l}\text { Jan.- } \\
\text { June. }\end{array}$ & $\begin{array}{l}\text { July- } \\
\text { Dec. }\end{array}$ & Totals. \\
\hline $\begin{array}{l}\text { Agriculture, Forestry, and } \\
\text { Horticulture }\end{array}$ & 9 & 7 & 16 \\
\hline Anthropology, Archæology . & 35 & 30 & 65 \\
\hline Biology . . & 66 & 41 & 107 \\
\hline Chemistry . . & 27 & 55 & 82 \\
\hline Engineering . & 19 & 17 & 36 \\
\hline Geography, Travel . . & 13 & 9 & 22 \\
\hline $\begin{array}{l}\text { Geology, Mineralogy, and } \\
\text { Mining }\end{array}$ & 12 & 17 & 29 \\
\hline $\begin{array}{l}\text { Mathematical and Physical } \\
\text { Science }\end{array}$ & 68 & 79 & 147 \\
\hline Medical Science, Physiology. & 8 & 22 & 30 \\
\hline Metallurgy . . . & 3 & 7 & 10 \\
\hline Meteorology & 7 & 2 & 9 \\
\hline Miscellaneous . . & 31 & 29 & 60 \\
\hline Philosophy, Psychology & 20 & 19 & 39 \\
\hline Technology & 10 & 10 & 20 \\
\hline & 328 & 334 & 672 \\
\hline
\end{tabular}

works on these subjects were noticed in our columns. It is also worth noting that while mathematics and physics claims 22 per cent of our review notices, biology comes second with 16 per cent.

The total number of publications reviewed during the year also requires comment. This number, 672, does not include the numerous references to publications made in "News and Views", "Research Items", "Astronomical Topics", "University and Educational Intelligence", and also in articles; many such publications are included in Table I. Hence we are justified in saying that considerably more than one-half of the publications received by NATURE are dealt with in our columns.

\section{Stock Diseases and Poisonous Plants}

A PAPER upon the "Poisonous Action of Ingested A Saponins", published as Bulletin 50 by the Council for Scientific and Industrial Research of the Commonwealth of Australia, has very general interest to stockbreeders and all who are interested in obscure diseases of stock in various parts of the world.

Prof. A. J. Ewart, of the University of Melbourne, suggests that various obscure stock diseases of Australia, America, New Zealand, and South Africa, like the 'walkabout disease' of horses in Australia, may be caused by the saponins present in the tissues of plants on which the animals graze. In the case of the 'walkabout disease', Prof. Ewart, in conjunction with Mr. D. Murnane, in 1927, produced the disease in six horses by feeding them, for periods of a month or more, with Atalaya hemiglauca, a plant rich in a hæmolytic saponin. Later, however, Dr. Seddon found that horses could be fed on fresh leaves of this plant for many months, in New South Wales, without any symptoms of disease developing.

Prof. Ewart now shows that, whilst the plant grows abundantly down to the twenty-fifth parallel, "walkabout disease ' only appears north of the nineteenth parallel. The reason seems to be that in the more southerly latitudes this plant contains less saponin and more of a tannin which protects against the hæmolytic action of the saponin. Tests of saponins by intravenous injection or by hæmolysis experiments are both difficult and expensive. Prof. Ewart shows that very good evidence of the toxic nature of the saponin (or extract) under investigation may readily be obtained by the use of the water snail Bulimus. Only plants containing a relatively higher percentage of saponin are likely to prove toxic, and then under conditions providing for continued grazing on the plant, as the saponins do not dialyse readily and only a small fraction of the ingested saponin is absorbed in the alimentary canal. This percentage absorption is increased by the use of purgatives or by inflammation of the alimentary canal. Species of Solidago, Aster, and Senecio are amongst the plants suspected of producing diseases of stock from this eause, the percentage of saponin in the dry leaves varying from 2 to 8 per cent in these species.

The Winton diseases of horses and sheep in New Zealand, characterised in chronic cases by pronounced cirrhosis of the liver, can be produced artificially by continuous feeding on the ragwort, Senecio Jacoboea.

\section{Post-Glacial Prehistory in Ireland}

UR knowledge of the post-glacial prehistory of northern Ireland is summarised by Mr. C. Blake Whelan in a recent communication to the Société Préhistorique française (Bull. 1931, 7.8). Although Chellean and Acheulean do not appear, it is possible to find in the gravels of north-east Ireland rare and doubtful specimens which appear to be humanly worked and may be examples of a pre-Mousterian, or even older, culture. The interesting Clactonian station of Rosses Point, Sligo, is an example. Yet up to the present, undoubted evidence of a true Mousterian of the Laufen interval between Würm I, and II. appears to be lacking. Man may have retreated southward and not returned until the great glaciations had definitely retreated from Ireland.

The same uncertainty obtains regarding postWürm II. The only undoubted Aurignacian station is on Rathlin Island. There may also be a true Aurignacian tradition in the implements from below the ancient flood level of the lower Bann. Although of undoubted antiquity, it is difficult to bring such finished specimens into relation with the crude implements which follow. To the Buhl-Gshnits interval belong a series of a palæolithic industry of remarkable facies from the $50 \mathrm{ft}$. raised beach of Antrim (see Nature, July 26, 1930, p. 133), which may belong to a period anterior to the Baltic Lake. It may be a belated Magdalenian or a new industry; but it has nothing in common with the European microlithic culture extending from the Reindeer period to the Maglemose. The period in Ireland really corresponding to the Baltic Lake is found in the peat at the base of the deposits of the estuary of the Lagan (Belfast), which are covered by an ancient estuarine clay, itself underlying the gravels of the $25 \mathrm{ft}$. raised beach.

In an analogous deposit at Larne is an industry thought to represent the final phase of the northern Magdalenian (see Nature, Sept. 6, 1930, p. 352). In the $25 \mathrm{ft}$. raised beach are found 'Asturian picks' mixed with a great quantity of roughly made implements which in the north are contemporary with the decline of the Magdalenian in the south-west. 'These may be the work of a race of pre-Mousterians driven north by the Aurignacians. At Glenarm is the preCampignian transition, and at Strangford Lough a number of stations mark the arrival of the true Campignian. Then comes the hiatus, followed by the neolithic and chalcolithic ages with their implements of classic upper palæolithic types, the final puzzle of the Irish stone age. 